\title{
TAQLID ITTIBA FOR MUKALLAF IN THE IMPLEMENTATION OF ISLAMIC LAW ON POSITIVE LAW IN INDONESIA
}

\author{
Hazar Kusmayanti ${ }^{1}$
}

\begin{abstract}
The Indonesian people in fact use their minds not on the basis of the Qur'an and the Sunnah is only limited to taqlid ittiba the religious scholars who are not necessarily truthful can be justified. The purpose to understanding of taqlid ittiba and to obtain the consequences of taqlid ittiba for Muslim in implementing Islamic Law and Positive Law. Research methods by using normative research methods or library law research in finding taqlid ittiba material for mukallaf. The results showed that the implementation of taqlid ittiba for mukallaf performed by Muslims is still a lot that is not in accordance with the teachings of Allah SWT and does not follow the Sunnah of Rasullah SAW. The implementation of taqlid ittiba that is wrong can harm oneself and others who can be troubling to the surrounding community. Someone who carries out taqlid ittiba that is not appropriate in the Qur'an and Sunnah has a legal consequence that is sinful because it does not follow the commands of Allah SWT and Rasul while according to the Law Positive in Indonesia taqlid ittiba allowed for someone who is an adult and does not violate the existing Positive Law so as to create peace between religious communities.
\end{abstract}

Keywords: Taqlid Ittiba, Mukallaf, Islamic law

\section{The Introduction}

Religion is a teaching that comes from God or the result of human contemplation contained in a sacred book that has been passed down from generation to generation with the aim to provide guidance and life direction for humans in order to achieve happiness in the world and in the hereafter that they hope not to believe for Strength the supernatural which further elicits emotional responses and the conviction of happiness in life depends on a good relationship with the supernatural powers (Asir, 2014:1).The religion of Islam, the majority of which is adhered to by the people of Indonesia, is one of the religions that teaches all aspects of life that govern themselves and regulate the relations of the surrounding communities which are studied in Islamic Law.

Islamic law is the basis and framework established by Allah SWT, not only regulating human relations with God but also regulating human relations with humans and regulating the pattern of life and behavior of the people, therefore the law as a social principle functions to regulate the relations between people in society. Human life in society is not only based on law but also based on human morality itself, which is governed by religion, moral principles, politeness, customs, and other social principles (Kusumaatmadja, 2006: 4.).Religion as a model of society,seen still managed as a hintResources used for the norms of life.Religious problems will not be

1 Fakultas Hukum Universitas Padjadjaran Bandung, Indonesia, Email: hazar.kusmayanti@unpad.ac.id 
possibledecide from people's lives, becausereligion itself is indeed needed withinsocial life. (Mulyadi, 2016:.560)

The development of Indonesian society which is increasingly advanced makes the basics of Islamic knowledge slowly begin to be abandoned, plus the State of Indonesia is a law state that adheres to National Law, as confirmed in Article 1 paragraph (3) of the 1945 Constitution IV Amendment stating that The country of Indonesia is a country of law. As a consequence of the rule of law, Indonesia must uphold the applicable law, all actions taken by the government and other state institutions and especially citizens must be based on law or can be legally accounted for. The basis and principle of Islam should be harmonized with the legal arrangements in Indonesia in order to balance the rights and obligations as citizens of Indonesia and as citizens who embrace Islam. These rights and obligations can be a justification for harmonizing the legal regulations in Indonesia with Islamic legal regulations.

Al-Qur'an and Sunnah as a source of Islamic Law should be able to be a guide or guide for mankind in life and life to prosper in this world and happiness in the hereafter (Ali 2006: 79). In this case the Indonesian people who adhere to the Islamic Religion do not abandon the Qur'an and Sunnah and also do not violate the laws governed in Indonesia.

Islamic law which is regulated in Indonesia through the way of thinking that arises in society today is still influenced by the habits of the previous Muslims which were inherited by the ancestors who were not actually regulated in the sources of Islamic Law namely the Qur'an and Sunnah. This is what causes the teachings of Islam to start to diverge and the mindset of people who are no longer in accordance with the actual guidance of the teachings of Islam, even though it is clear the Qur'an was revealed to explain all events, as stipulated in the Al-Qur'an Letter An- Nahl verse (89) which means:

"We send the Qur'an to You, O Muhammad. To explain all events. "

Some Islamic societies in Indonesia have not preserved the sanctity of the teachings of the Qur'an and Sunnah, undermining the firmness set by God. The source of Islamic law cannot be changed, added, or reduced so that Muslims should fully comply with the teachings of Islam that already exist. In addition to the Qur'an and Sunnah there are other sources of Islamic law that can support the implementation of the teachings of true Islamic law, namely the human mind that meets the requirements to try, endeavor with all the capabilities available to him, understand the fundamental rules of law contained in Al-Qur'an, general legal norms contained in the Sunnah of the Prophet and formulating them into legal lines that can be applied to a particular case, or trying to formulate lines or legal norms where "arrangements" are not available in the two main sources of Islamic law(Ali 2006: 79).

In fact, a human who has a mind needs God's guidance, because besides humans are weak and forgetful, in themselves there are obstacles that cause humans to be unable to use their minds properly and correctly. The Koran as the last book is intended to be a guide for all mankind (hudan linnas) until the end of time. Not only for members of the Arab community where this book was revealed but for all humanity. It contains noble values that cover all aspects of human life in dealing with God and human relations with other fellow humans and human relations with the natural 
surroundings, therefore humans must regulate their lives and environment in accordance with the guidance of Allah SWT and obey follow the instructions given by Allah SWT. With thus the Qur'an, Sunnah and reason have a close relationship and are the source of Islamic teachings. The Qur'an and reason are neither the same nor the same, the Qur'an has a higher position than human reason. Al-Qur'an which guides and guides and measures human reason, not vice versa. When connected with the law, then for those who believe in God Almighty, the Law of God delivered with the Qur'an is higher and more important than the laws created by humans. This also means that the law produced by the human mind cannot contradict the law delivered through the Qur'an (Daulay, 2014: 31 ).

The Indonesian people in fact use their minds not on the basis of the Qur'an and Sunnah only to the extent of taqlid ittiba (following) the religious scholars who are not necessarily responsible for their truth, so it needs to be done by people who meet the requirements from time to time, because of Islam and the Ummah Islam also developed from time to time in accordance with the development of society. In a developing society, problems always arise that need to be resolved and determined by the rule of law. The word taklid is derived from the word qallada-yuqallidu-taqlidan, which means to surround, decorate, imitate, submit, and follow. Imitation can also be defined as accepting the opinions of others by not being able to state their reasons Someone who acts as if hanging the law he followed from a mujtahid (Hanafi, 1984: 176).

Allah SWT has obliged every believer to obey and follow (ittiba) the Qur'an and Sunnah because it is obligatory for every mukallaf (one who is burdened with legal obligations) to always follow God's command in full and right. Allah SWT has intended the Islamic Religion for humans who are upheld above science, so that in every implementation of Islamic Law must be based on science. Taqlid ittiba is not a science, so people who do taqlid ittiba must not say that what they do is completely right, because the truth comes only from Allah SWT.

The taqlid ittiba case that is being widely discussed by the public is the MUI Fatwa concerning the prohibition of smoking, the forbidden fatwa issued by Muhammadiyah lately raises the pros and cons of the community, for those who benefit from the cigarette business, of course the haram fatwa must be opposed because it is very detrimental, while for the anti-smoking especially mothers and children who have been disturbed by cigarette smoke even because cigarettes husband's income for the family is reduced, haram fatwa may be the right solution. Other scholars who reject the forbidden fatwa argue that there is no single science, either in the form of verses of the Qur'an or the Hadith that explicitly and definitely mentions the prohibition of cigarettes, therefore humans are encouraged to do taqlid ittiba to the prohibited fatwa of smoking but as a way the middle is being issued a fatwa makruf for cigarettes, as things that should be avoided and the level is slightly below haram. The issuance of fatwa forbidden cigarettes as carried out by Muhammadiyah, is none other than the strengthening of health awareness, the scholars who support the fatwa of illicit cigarettes seem to be justified in scientific studies of the dangers of smoking and in the Islamic Law of Allah SWT explained in the letter Al-Baqarah verse 195. 
Another taqlid ittiba case is the MUI Fatwa on the prohibition of abstentions (White Group), a number of politicians' proposals including Hidayat Nur Wahid to proclaim Abstentions which were originally in response to the attitude and appeal of KH. Abdurrahman Wahid (Gus Dur), finally responded by the Indonesian Ulema Council (MUI). MUI has issued a fatwa forbidden to the white group, so that Muslims have no other choice except choosing political parties, legislative candidates and presidents in the next election. Islam regulates the making of an unlawful halal decision is not an easy matter, normatively doing something that is forbidden will get sin as well as leaving obligations, if read from this logic, then Muslims who do not vote in the election will get sin, so normatively will be tortured, therefore the decision to convict an unlawful fatwa against political phenomena such as abstentions must be taken with seriousness and caution.

Al-Qur'an and Hadith there are no provisions for Muslims to vote in the election. This MUI fatwa is based on the results of ijtihad by exploring the source of Islamic law, therefore the quality of the prohibition issued by the MUI fatwa is not as strong as haram for eating pork, so also, the obligation to follow the fatwa of the ulama is not like the obligation to pray, fasting, zakat and hajj so that humans Lay people are obliged to do taqlid ittiba or follow MUI Fatwa as long as it is good for other people, as a result of ijtihad against political phenomena of abstentions fatwa abstentions is nothing more than a moral appeal that does not have the power to impose sanctions for those who violate them, even the abstentions fatwa as an effort for the birth of good leadership.

Based on these cases, Islam advocates such ijtihad, even in the Islamic tradition it is stated that when the result of ijtihad is wrong, one still gets a reward from the ijtihad process, a fatwa is born from an ijtihad on a certain phenomenon in society. Modernization in Indonesia is growing and Islamic teachings are fading with the times and legal regulations in Indonesia are weak in its firmness, making people far from the structure of Islamic Law and law in Indonesia. This makes the Muslims in Indonesia do things that are already outside the corridor of the actual regulations. Al-Qur'an and Sunnah are no longer the source of real guidance, the community only follows (taqlid ittiba) the Islamic scholars whose source is unclear.

Based on the description above, the problems in this study were identified in the following matters: How is the implementation of taqlid ittiba (following) related to Islamic Law and Positive Law in Indonesia?; and, What is the consequence of taqlid ittiba law for believers in the implementation of Islamic Law and Positive Law in Indonesia?

\section{Research Methods}

The research method used in writing this research is to use normative research methods or library research (Soekanto \& Pamuji, 2011: 58). The type of data used is secondary data consisting of primary, secondary and tertiary legal literature obtained by searching through libraries, legal documentation centers, through the internet media. Research specifications are analytical descriptive intended for provide data as complete as possible and provide a clear picture of what is the object of research on taqlid ittiba for mukallaf in the implementation of Islamic Law against Positive Law in Indonesia. The purpose of this study is expected to formulate what is the main problem in 
the object of research on taqlid ittiba for Muslim believers in the implementation of Islamic Law against Positive Law in Indonesia.

\section{Discussion and Results}

\section{The Implementation of Taqlid Ittiba for Mukallaf Is Linked to Islamic Law and Positive Law in Indonesia}

Islamic law learns that humans are given by Allah SWT a variety of very valuable equipment including reason, will and ability to speak, with reason humans can distinguish between right and wrong, the good with the bad between reality and fantasy (Fu'adi, 2012:568 ). Humans by using the mind will always be aware and can choose the life they pass correctly, reason can also be used for taqlid ittiba (following) the commands of Allah SWT. Islamic scholar in Indonesia have done a lot of ijtihad to find a way out of the problems of Islamic law that can be a guide for ordinary people, if the problem is not in the main sources of Islamic law, namely the Qur'an and Sunnah. Muhammad Rasyid Ridha, one of the ulemas in Indonesia formulated taqlid ittiba with the facts that exist in Islamic society, because according to him taqlid ittiba is to follow the opinions of humans who are considered respectable in society and trusted in Islamic Law without regard to right or wrong, both bad and bad benefit or not the opinion (Koto, 2009: 132). The science of jurisprudence also formulates its views on taqlid ittiba, namely following the opinion of a particular ulama without knowing the source and method The opinion taking, the means of carrying out taqlid ittiba is ijtihad, the ulama in Indonesia interpret ijtihad with efforts to devote all abilities and intellectual abilities and to look for practical laws taken from detailed opinions or as formulated by $\mathrm{Abd} \mathrm{Al}-\mathrm{Wahab} \mathrm{Al}-\mathrm{Khallaf}$ namely provide excellent ability to produce Islamic law and guided by the Qur'an and Hadith (Koto, 2009:132).

Positive law in Indonesia regulates taqlid ittiba as well as in formal legal sources, one of which is doctrine, but doctrine is not binding such as laws, treaty customs and jurisprudence. Doctrine only has authority which is considered objective and can be used as a source of legal discovery for judges, according to Sudikno Mertokusumo doctrine is a source of law. but it is not law because it does not directly have the binding power as the law, new jurisprudence is binding and has legal force when used as legal considerations in court decisions. The judge in determining his attitude who is right and who is not right, then the judge must first know objectively to sit the actual case as the basis for the decision through the evidences not based on a priori finding a decision, while the consideration of the proof is then constructed (constructed). After the judge considers the event to be disputed, the judge has been able to confirm (declare proven) the event that is the dispute, then the judge must find the law against the dispute of both parties, where the judge must qualify the event he considers to be proven (Maggalatung, 2014:91).

The basic principle of ijtihad is the result of philosophical thinking, so that the results of ijtihad are part of the work of human reason and can be taqlid ittiba by the whole community, according to experts in the field of Islamic Law, reason is the principle of ijtihad, especially in the fields of Islamic Law that is not regulated in the Qur'an and Hadith, but that does not mean that reason can work on the basis of their own volition and methods 
without going through proper knowledge, because the work process of ijtihad uses thought with the correct knowledge under the guidance of the Qur'an ' an and Hadith and refrain from lust.

Humans who have extensive knowledge in studying Islamic law, especially taqlid ittiba and ijtihad, are required to have good reasoning and mastering sciences such as Arabic knowledge, Qur'anic science, Hadith science, and knowledge of the basics The religion of Islam, because the use of reason aims to resolve religious issues, whether of a worldly or finality, but because of religious issues, in general have been regulated in detail and clearly by the Qur'an and the Hadith, then the problems that have been arranged should not be or illegitimate the law there is human interference in it, whereas that has not been regulated in the Qur'an and the Hadith can be done by scholars with the method of ijtihad and humans who are unfamiliar with Islamic Science can taqlid ittiba to the results of ijtihad of the islamic scholars (Maggalatung, 2014:91).

The result of (ijtihad) thinking of the ulama, or often called fatwa, in Indonesia mostly comes from the Indonesian Ulema Council (MUI). An Indonesian Muslim ulama organization that is recognized by the government and is considered representative as a referral institution for various problems of the Ummah. Associated with contemporary problems faced by Muslims, MUI has the duty to provide answers to various questions posed with, of course, based on recognized Islamic legal foundations. It is in this context that the MUI is authorized to conduct ijtihad and issue fatwas on various problems of Muslims (Ghafur, 2007).

The results of ijtihad of the ulama are regulated in the fatwa, which in Indonesia is regulated by the MUI (Indonesian Ulema Council), one of the fatwas that has been issued by the MUI is the forbidden fatwa on smoking, those who oppose the prohibition of smoking forbidden are actually also numerous, the public recognizes that smoking is basically indeed especially detrimental to body health, however The community also admitted that there were not a few donations from cigarette entrepreneurs, one of which was scholarships for students, sponsorship of environmental programs, community empowerment, coaching for sports athletes, and others.

Forms of warning to connoisseurs and cigarette addicts actually already in cigarette packaging that is clearly written smoking can lead to heart attacks, cancer, impotence and disorders of pregnancy and fetus, but it seems that the warning only becomes meaningless writing, because day by day the number of smoking addicts is increasing in this country, not only adult men who have worked, but school children have also started to become addicted to goods containing nicotine. MUI fatwa on the prohibition of smoking is actually issued on the basis of the thought of the scholars, MUI should be able to provide a clear explanation to the people about the basis for the determination of the forbidden fatwa, so it is not controversial anymore.

The fact needs to be thought about the disadvantage side in terms of the benefits of smoking, if it is true that there are many disadvantages, then the MUI is obliged to immediately ratify the illicit fatwa for cigarettes, but if the basis is unclear and harms the people, the fatwa must be revoked immediately. Because there is no argument that says that smoking or smoking is forbidden, so the MUI will not make a decision that can justify something that is unlawful and otherwise forbid the halal, but issue a fatwa 
forbidding cigarettes also aims to strive for maintenance and improvement of public health as part of the purpose of sharia (Islamic law). Muhammadiyah PP Chairman Yunahar Ilyas said that the forbidden fatwa is the ijtihad of the ulama which can be followed by lay people.

The rationale underlying the decision that smoking is illegal is because smoking is included in the category of doing khabaa'its (dirty or unclean) which is forbidden in Al Quran Surah Al a'raf verse (157). The act of smoking contains an element of falling into destruction and even is a slow suicide so it is contrary to the prohibition of Al-Baqoroh verse (2) and An-Nisa verse (29). Smoking is harmful to oneself and other people affected by cigarette smoke because cigarettes are addictive substances plus it contains 4000 chemicals, 69 of which are carcinogenic or cancer triggers (Fact Sheet TCSC-AKMI or Tobacco Facts in Indonesia), as agreed by the medical experts and health academics, therefore smoking is contrary to the principles of Islamic Law set forth in the Hadith of the Prophet Muhammad SAW that "there is no act of endangering oneself and endangering others." Cigarettes are recognized as addictive substances and contain dangerous elements of poison even though not immediately but in a later time, therefore smoking is included in the category of doing something that weakens so contrary to the Hadith of the Prophet Muhammad that prohibits any intoxicating and debilitating case. (Trigiyatno 2011:67)

Considering that the dangers of smoking outweigh the benefits, automatic smoking is analogous to the Qur'anic verse that talks about liquor (khamr), it is recognized that liquor has benefits but the danger is greater, as regulated in Surah Al-Baqarah verse (219) which means:

"They ask you (Muhammad) about khamar and gambling. Say, in both of them there are big sins and some benefits for humans. But the sin is greater than the benefit, And they ask you (about) what (they must) give, Say, Strength (of what is needed). Thus Allah explains His verses to you so that you think. "

This smoking haram fatwa is actually intended for children or someone who has not reached the age of 21 years, as regulated in Presidential Instruction of the Republic of Indonesia Number 1 of 1991 Concerning Compilation of Islamic Law Article 107 paragraph 1 says that a person who is not yet an adult (children) under guardianship who have not yet reached the age of 21 years and or have never entered into a marriage. Cigarettes are also forbidden for teenagers, pregnant women, and in public places. Seto Mulyadi, Chairperson of the National Commission for Child Protection, strongly supports the fatwa, because it aims to save children as the nation's next generation from the dangers of cigarette poison.

The Result of Taqlid Ittiba's Law for Mukallaf in the Implementation of Islamic Law and Positive Law in Indonesia

The formation of Islamic Law that occurred in Indonesia has suffered a setback, this can be seen from the spirit of freedom and independence thinking the scholars have disappeared, many scholars in Indonesia no longer make the Qur'an and Sunnah as the main source but instead have been satisfied with the way of taqlid and by holding on to the previous jurists namely Abu Hanifa, Malik Shafi'i, Ahmad bin Hambal, and others. Ulemas in Indonesia have narrowed their mind space to a limited environment 
regarding the branches of law, forbid themselves outside the boundaries of the taqlid ittiba environment, the scholars only devoted all their ability to understand the words and expressions in doing taqlid ittiba to experts previous jurisprudence (Khallaf, 2002 :113).

The implementation of taqlid ittiba in Indonesia is still many that deviate from the teachings of the true Islamic Law which is guided by the Qur'an and the Hadith, humans only follow or taqlid ittiba to hereditary traditions, even though these actions are not in accordance with the commands of Allah SWT in Surat Azab verse 64 which means:

"Verily Allah curses infidels and provides for them a blazing fire. They are eternal in it, they have neither protection nor help. On that day their faces were turned over in the fires of hell, they said, it would be nice if we obeyed Allah and the Apostle. And they say, $O$ our Lord, in fact we have obeyed our leaders and dignitaries, then led us astray".

Humans who follow something unknown ability and expertise and exceed his love for himself then Allah will give a very severe torture, because to do taqlid ittiba must be in accordance with the teachings of Islam can not be done haphazardly as ordered by Allah SWT in Surat Al -Baqarah verses 165-166 which means:

"Among humans there are those who follow many bonds besides God and love God. As for those who believe, love Allah deeply. If those who commit wrongdoing when they see the doom (on the Day of Judgment) that in fact the power belongs to God all, then God is very painful torture. (Namely) when the people they follow disassociate from them when they see the doom and break all relations".

Taqlid ittiba method is an obligation that must be fulfilled only by some people who are able to carry it out, that is for humans who are adults or converts when the problem of Islamic Law is not contained in the Qur'an and Sunnah, therefore ijtihad in taqlid ittiba is built as a religious obligation, ijtihad must be practiced in every case by capable human beings as well as ordinary people must act according to what is considered appropriate and if the scholars get a solution when the problem is still present then ordinary people must follow the solution (Wael B Hallag2000: 36). Considering that not all humans have the ability to understand Islamic law directly from its source, even in intelligence, capture and scientific means are different. Humans who have the ability to perform jijtihad with all the requirements, it is permissible to carry out an excavation and understanding directly from the source. However, for someone who has not, even does not have the ability at all, then in fact, the existence of taqlid ittiba is still dominant for humans.

It is permissible for a person to follow a particular opinion because of his inability to understand the science of religion and by following a certain opinion, can prevent it from the adverse effects arising from ignorance of the case of Islamic Law(Zainuddin Ali, 2006: 50) One is forbidden to make a new opinion which was never conveyed by the ulama, but if the opinion is based on the Qur'an and Sunnah, then it is permissible to do ijtihad on its own. Misdirection is the result of taqlid ittiba someone against the teachings of the ancestors, the limitations of his mind, and / or desires that led him into disobedience to Allah SWT and His Messenger who deviated from the Qur'an 
and Sunnah. This is the reason why people reject the teachings of Islam and do not apply it properly and correctly.

A person who is lay in doing taqlid ittiba or follows a cleric who has deeply understood religion is obligatory, because not everyone has the ability and opportunity to study religion in depth. As instructed by Allah SWT in Surat At-Taubah verse 122 which means:

"It is not proper for believers to go to the battlefield all, there should be a group from each group of them left to deepen their religion and give warnings to their people when they return to him, hopefully they are afraid".

Based on an interview with HM. Salim Umar Chairperson of the West Java MUI Fatwa Commission for the Implementation of taqlid ittiba for mukallaf can be haram if humans who clearly follow (taqlid ittiba) to others who are not based on the Qur'an and Sunnah and in evil, such as someone who follows others in shirk or disobedience. If humans already know that it turns out that the ulama violates the strictness in the Qur'an and Sunnah, then at that time humans are obliged to return to the Qur'an and Sunnah. Ulema who have been able to do ijtihad or have reached the degree of mujtahid (ijtihad experts), the ulama is forbidden to taqlid ittiba to other scholars, because the scholars have been able to do jihad, then it is obligatory to do the jihad itself based on the knowledge available to the scholars and with all the abilities that exist. the ulama, if the ulama's opinion is correct in its ijtihad, then the ulama gets two rewards, and if the ulama's opinion is wrong in his ijtihad, then he gets one reward.

For people who fulfill the requirements of ijtihad, it is obligatory for them to perform jihad and practice the results of their ijtihad. Not justified / forbidden for him bertaqlid or follow the opinion of other mujtahid. It is in this direction that we must understand the words of well-known mujtahid imams such as Hanafi, Shafi'i and others who forbid taqlid. That is, for those who are able to do their own pilgrimage because they have fulfilled their requirements, do not follow or make tribute to other mujtahids, but are obliged to do their own ijtihad (Al Farizi, 2014: 10).

Allah SWT reminds all people not to follow something that is clearly wrong, but people sometimes because they feel they have to respect someone or are fanatical about a group and then followed. Obviously this is very despicable for Allah SWT, then Humans who are ignorant of Islamic knowledge and do not have the ability to do ijtihad are encouraged to ask the scholars, however according to Al-Dahlawy taqlid ittiba allowed is taqlid ittiba in the sense of following the opinions of the scholars, because there has not been found the Law of Allah SWT and the Prophet SAW regarding the an act.

Humans who taqlid ittiba must continue to learn to deepen the knowledge of Islamic Law, because if one day the person concerned found an opinion that something that was preached as it is contrary to the Religion of Allah SWT, then the human must leave the opinion that was taqlid ittiba earlier (Rohadi Abdul Fatah2010.,133-135). Humans do not all have the ability to understand Islamic law directly from its source, even in intelligence, catch and different scientific facilities of humans. Humans who have the ability to perform ijtihad with all the requirements, are allowed to carry out an excavation and understanding directly from the source, but for 
humans who have not, even do not have the ability to taqlid ittiba, are allowed to do ijtihad as long as they do not deviate from the teachings of $\mathrm{Al}$ Qur'an and Hadith.

Based on an interview with Mr. Isep Zaenal Arifin, Head of the Islamic Guidance and Counseling Department of UIN Sunan Gunung Jati Bandung Taqlid Ittiba is not a good scientific method, because to obtain a good knowledge with the validity of science that can be accounted for can only be achieved through nadhar methods, namely through a method reasoning, research, and careful and in-depth study. From these factors the majority of scholars agreed to declare that taqlid ittiba cannot be used as a basis for taking law in the field of creed, then an agreement emerged from the scholars to make a concept of taqlid ittiba by saying that the legal basis of an aqeedah is the Qur'an and Sunnah.

The concept of taqlid ittiba can be stated that people who have fulfilled the requirements and means of jihad are not allowed to follow taqlid ittiba (following) the opinions of others by violating the results of their own ijtihad, because someone is required to always be consistent in practicing their own ijtihad results. Taqlid ittiba carried out by the people of Indonesia are still many that do not fit in the Qur'an and Sunnah, as is the case in the fatwa forbidden white group (abstentions). A group of people who do not take part in the presidential and vice-presidential elections, even though this abstention fatwa is not compulsory and intended by someone who is an adult or Muslim, such as performing prayers, fasting, zakat, and pilgrimage, but abstention fatwa is an effort to give birth to good leadership that is good really select society. On the other hand, the abstentions fatwa is a compelling decision for people who have the right not to vote and can also violate human rights, therefore the role of government is needed in the strictness of the application of regulations so that people do not become confused and determine their choices with well.

Based on the case outlined above, Islamic law teaches taqlid that the law is mandatory for every Muslim who is a convert or an adult who is unable to perform Ijtihad. This can be seen from the positive law in Indonesia which applies a person who is not yet an adult to carry out legal actions, namely a child who has not reached the age of 18 years or has never entered into a marriage regulated in (Article 1330 of the Civil Code Book jo Article 47 of Law Number 11974 concerning Marriage), whereas in Law Number 10 of 2008 concerning General Elections of Members of the House of Representatives, Regional Representatives, and Regional House of Representatives it is not confirmed how many years old it is, but only states in Article 12 letter a that the right to vote is an Indonesian citizen who is 21 (twenty one) years of age or older.

Someone who is under the supervision of adults, but in a state of dumb, crazy, dark eyes, and wasters regulated in (Article 1330 of the Civil Code jo Article 433 of the Civil Code), someone who is prohibited by the law to carry out certain legal actions, for example, a person is declared bankrupt (Article 1330 of the Civil Code and the Bankruptcy Law),(Vitra Hana Sharfina, Satria Sukananda 2019: 312). whereas in Article 1 paragraph (1) of Law Number 23 Year 2002 Concerning Child Protection it is said that a child is a person who is not yet 18 (eighteen) years old, including a child who is still in the womb. 


\section{Conclusion}

The implementation of taqlid ittiba for mukallaf carried out by Muslims is actually still a lot that is not appropriate and deviates from the teachings of Allah's Religion and does not follow the Sunnah of Rasullah SAW. The implementation of taqlid ittiba which is wrong can harm oneself and others who can be troubling to the surrounding community, therefore taqlid ittiba is carried out to seek the truth that is beneficial to the wider community and someone who is followed for taqlid ittiba must also have high Islamic knowledge such as scholars and not deviate from the sources of Islamic Law, namely the Qur'an and the Hadith. As for someone who carries out taqlid ittiba that is not appropriate in the Qur'an and Sunnah has a legal consequence that is sinful, because it has deviated from the teachings of Allah's Religion, but if someone who performs taqlid ittiba does not know that those who are preached deviate from Al- Qur'an and Sunnah, the science of jurisprudence will be damaged, whereas according to Positive Law in Indonesia taqlid it is permissible for someone who is an adult and does not violate the existing Positive Law so as to create peace between religious communities.

\section{References}

Asir, Ahmad. (2014). Agama dan fungsinya dalam kehidupan umat manusia. Jurnal al- Ulum: Jurnal Pemikiran dan Penelitian ke-Islaman, 1(1), 5058. https://doi.org/10.31102/alulum.1.1.2014.50-58

Al Farizi, Mudrik. (2014). Ijtihad, taqlid, talfiq. Al-Mabsut: Jurnal Studi Islam dan Sosial, 8(1), 115-134.

Ali, Mohammad Daud. (2006). Hukum Islam, pengantar ilmu hukum dan tata hukum Islam di Indonesia. PT RajaGrafindo Persada.

Ali, Zainuddin. (2006). Hukum Islam pengantar ilmu hukum Islam di Indonesia. Sinar Grafika.

Daulay, Muhammad Roihan. (2014). Studi pendekatan al-quran. Thariqah Ilmiah: Jurnal ilmu-ilmu kependidikan dan Bahasa Arab, 1(1), 31-45. https://doi.org/10.24952/thariqahilmiah.v1i01.254

Fatah, Rohadi Abdul. (2010). Analisis fatwa keagamaan dalam fikih Islam. Bumi Aksara.

Fu'adi, Athok. (2012). Peran pendidikan pendidikan agama dalam membentuk manusia yang bekeadaban publik. Millah, X I(2), 559-578. https://doi.org/10.20885/millah.volxi.iss2.art11

Ghafur, Muh. (2007). Dinamika Fatwa MUI. Asy-Syir'ah, IV(I)

Hanafi, A. (1984). Pengantar dan sejarah hukum Islam. Bulan Bintang.

Hallag, Wael B. (2000). Sejarah teori hukum Islam pengantar untuk usul fiqh mazhab sunni. PT RajaGrafindo Persada.

Khallaf, Abdul Wahab. (2002). Sejarah pembentukan dan perkembangan hukum Islam. PT. RajaGrafindo Persada.

Koto, Alaiddin. (2009). Ilmu fiqh dan ushul figh. PT RajaGrafindo Persada.

Karimuddin, Muhammad Zuhdi. (2019). Kedudukan mahzab, taklid dan ijtihad dalam Islam. Al-Qadha: Jurnal Hukum Islam dan PerundangUndangan, 6(1), 55-65. https://doi.org/10.32505/qadha.v6i1.1291

Kusumaatmadja, Mochtar. (2006). Konsep-konsep hukum dalam pembangunan. PT. Alumni 
Maggalatung, A Salman. (2014). Hubungan antara fakta norma, moral, dan doktrin hukum dalam pertimbangan putusan hakim. Jurnal Cita Hukum, 2(2), 185-192. https://doi.org/10.15408/jch.v1i2.1462

Mulyadi. Agama dan Pengaruhnya dalam Kehidupan. Jurnal Tarbiyah AlAwlad, 6(2)

Soekanto, Soejono. \& Pamuji, Sri. (2013). Penelitian hukum normatif suatu tinjauan singkat. Raja Grafindo Persada.

Sharfina, Vitra Hana. \& Sukananda, Satria. (2019). Perlindungan hukum atas hak keperdataan bagi orang yang berada dalam pengampuan (Studi kasus Penetapan Nomor 0020/Pdt.P/2015/PA.Btl.). Justitia Jurnal Hukum, 3(2), 319-337. http://dx.doi.org/10.30651/justitia.v3i2.3650 